\title{
Pengaruh Terapi Bekam terhadap Tekanan Darah pada Penderita Hipertensi: Studi Quasy Eksperimental
}

\author{
Nuridah $^{1}$ dan Yodang ${ }^{2}$ \\ 1,2Universitas Sembilan Belas November Kolaka \\ nuridah.usnkolaka@gmail.com ${ }^{1}$
}

Diajukan 6 Januari 2021 Diperbaiki 3 Februari 2021 Diterima 9 Februari 2021

ABSTRAK

Latar Belakang: Hipertensi sebagai penyakit tidak menular saat ini sangat meningkat dan merupakan penyakit pembuluh darah yang dapat menyebabkan terjadinya kematian mendadak sehingga penyakit ini dikenal sebagai silent killer. Meningkatnya persentase ketidakpatuhan meminum obat hipertensi disebabkan berbagai alasan dan hal ini membuat banyaknya pengobatan non-farmakologi yang bersifat alternatif dan komplementer yang bermunculan, salah satunya adalah terapi bekam.

Tujuan: Untuk mengetahui pengaruh terapi bekam basah pada penderita hipertensi dalam menurunkan tekanan darah.

Metode: Desain penelitian yang digunakan dalam penelitian ini adalah quasy eksperimen dengan pendekatan Control Group Design pre-post test. Populasi dalam penelitian ini adalah penderita hipertensi yang berada di wilayah kerja Puskesmas Kolaka yang memenuhi kriteria inklusi. Teknik pengambilan sampel dengan purposive sampling dengan jumlah sampel sebanyak 40 responden. Instrumen dilakukan dengan pengukuran tekanan darah dengan menggunakan alat pengukuran tekanan darah dan data dianalisis dengan menggunakan uji friedman test.

Hasil: Setelah dilakukan pembekaman basah selama tiga bulan berturut-turut, tekanan darah sistole dan diastole mengalami penurunan secara signifikan pada kelompok intervensi sebesar $0,000(\mathrm{p}<0,05)$ dan kelompok kontrol ( $\mathrm{p}>0,05)$ sehingga disimpulkan bahwa ada perbedaan rata-rata tekanan darah pada ketiga interval waktu pengukuran pada kelompok intervensi.

Kesimpulan: Terapi bekam memiliki pengaruh dalam menurunkan tekanan darah pada penderita hipertensi.

Kata Kunci: Bekam Basah; Hipertensi; Terapi Alternatif; Terapi Komplementer

\section{ABSTRACT}

Background: Hypertension as a non-communicable disease is currently increasing and is a blood vessel disease that can cause sudden death so that it is known as a silent killer. The increasing percentage of non-adherence to taking hypertension drugs is due to various reasons and this has led to the emergence of many alternative and complementary non-pharmacological treatments, one of which is cupping therapy.

Objective: This study aimed to determine the effect of wet cupping therapy on hypertensive patients in reducing blood pressure.

Method: This was a quasi-experiment with a pretest and posttest control group design. The sampling technique was purposive sampling, consisting of 40 respondents who were divided into two groups. The data analyzes used the Friedman test.

Results: After three consecutive months of cupping therapy, both systolic and diastolic blood pressure decreased significantly in the intervention group with a p-value of $0.000(p<0.05)$, while the control group with a p-value of more than 0.05. There was a difference in mean both systolic and diastolic at all three intervals of measurements in the intervention group.

Conclusion: Cupping therapy has potential benefits in reducing blood pressure among hypertensive patients.

Keywords: Wet cupping; Hypertension; Alternatives therapy; Complementary Therapy; Hypertensive Coastal residents 
PENDAHULUAN

Hipertensi merupakan peningkatan tekanan darah sistolik lebih dari 140 $\mathrm{mmHg}$ dan tekanan darah diastolik lebih dari $90 \mathrm{mmHg}$ pada dua kali pengukuran dengan selang waktu lima menit dalam keadaan istirahat atau relaksasi yang cukup (Kemenkes RI, 2018). Namun demikian, penyakit ini merupakan salah satu dari dua faktor risiko utama independen di dunia untuk penyakit kardiovaskular dan menjadi faktor utama di Indonesia sebagai penyebab terjadinya kerusakan organ jantung, pembuluh darah, ginjal, paru-paru, sel-sel saraf motorik dan sensoris, bahkan mental manusia. Akibatnya, hipertensi juga dikategorikan sebagai the silent disease atau bahkan the silent killer, dengan risikonya yang lebih dari $20 \%$ atau 1 dari 5 penderita hipertensi akan berisiko mengalami kematian (Mukhlis et al., 2020).

Menurut WHO, hipertensi sebagai salah satu penyakit tidak menular bertanggung jawab atas $45 \%$ kematian akibat penyakit jantung dan 51\% kematian akibat strok. Dilaporkan bahwa sekitar $40 \%$ orang dewasa di atas 24 tahun telah didiagnosis hipertensi meningkat dari 600 juta pada tahun 1980 menjadi 1 miliar pada tahun 2008. Prevalensi hipertensi tertinggi di Afrika adalah $46 \%$ orang berumur dari 25 tahun ke atas, sedangkan prevalensi terendah ditemukan di Amerika Serikat dalam 36\% kasus (Kemenkes RI, 2014).

Walaupun terlihat besaran persentase penyakit hipertensi tidak sebesar di negara-negara maju, hipertensi termasuk penyakit tidak menular yang cukup besar secara nasional $(25,8 \%)$ dengan persentase tertinggi 30,9\% di Bangka Belitung dan terendah 16,8\% di wilayah Papua. Keadaan tersebut juga dilaporkan bahwa, dari $1 / 3$ orang yang terdiagnosis dengan hipertensi, hanya $0,7 \%$ yang minum obat. Hal ini menggambarkan bahwa sangat rendahnya kesadaran masyarakat dalam memahami bahaya hipertensi yang mengancam jiwa (Kemenkes RI, 2018).

Pengobatan non-farmakologis atau pengobatan alternatif lebih disukai oleh sebagian orang, terkait dengan persepsi masyarakat tentang efek samping konsumsi bahan kimia dan kondisi ekonominya. Pengobatan alternatif umumnya dilakukan dengan menggunakan obat-obatan herbal dan cara tradisional yang sesuai dengan kepercayaan turun temurun dan agama mereka. Salah satu alternatif yang dipilih sebagai terapi komplementer adalah bekam. Pengobatan ini selain sangat terjangkau dengan akses lingkungan yang nyaman dan aman juga sangat dianjurkan karena kemanjuran dan keterjangkauannya (Syahputra et al., 2019).

Dalam istilah bahasa, bekam berarti menghisap. Bekam merupakan sebuah metode dengan mengeluarkan darah hasil metabolisme atau darah yang terkontaminasi racun dan oksidan dari tubuh lewat permukaan kulit. Cara ini dianggap lebih aman dibandingkan dengan cara pemberian obat antioksidan atau obat kimia lainnya. Bekam basah dianggap lebih efektif untuk berbagai penyakit, terutama penyakit yang berkaitan dengan gangguan pada pembuluh darah. Berbeda dengan bekam kering yang mungkin hanya menyembuhkan penyakit ringan, bekam basah dapat membantu mengatasi penyakit yang lebih parah, akut, kronis atau degeneratif, seperti hipertensi (Widada et al., 2019).

Manfaat bekam pada hipertensi merupakan sebuah proses menurunkan sistem saraf simpatis dan membantu pengontrolan kadar hormon aldosteron di sistem saraf. Kemudian, hal tersebut merangsang sekresi enzim yang bertindak sebagai sistem angiotensin renin yang dapat menurunkan volume darah, dan mengeluarkan oksida nitrat yang berperan dalam vasodilatasi pembuluh 
Pengaruh Terapi Bekam terhadap Tekanan Darah...

darah sehingga penurunan tekanan darah dapat terjadi. Selain itu, sifat terapi preventif dari kejadian hipertensi sangatlah kuat sehingga sangat dianjurkan sebagai sebuah terapi komplementer dari pencegahan dan pengobatan hipertensi (Rahman et al., 2020). Bekam melalui oksida nitrat akan meningkatkan suplai nitrasi dan darah yang dibutuhkan oleh sel dan lapisan arteri dan vena, yang menjadikannya lebih kuat dan lebih elastis serta mengurangi tekanan darah. Bekam berperan dalam merangsang reseptor spesifik yang berhubungan dengan penyusutan dan peregangan pembuluh darah (baroreseptor) sehingga pembuluh darah dapat merespon rangsangan dan meningkatkan kepekaan terhadap penyebab hipertensi (Muflih \& Judha, 2019).

Beberapa penelitian sebelumnya telah mengujicobakan bekam dalam melihat respons tekanan darah, tetapi efektivitas jangka panjang belum dapat diobservasi lebih lanjut dalam penelitian tersebut. Oleh karena itu, dalam penelitian ini, fenomena tersebut dilihat dengan melakukan intervensi dalam kurun waktu tiga bulan dengan intervensi pembekaman secara berturut-turut dengan tujuan untuk melihat pengaruh terapi bekam pada penderita hipertensi.

\section{METODE PENELITIAN}

Penelitian ini merupakan quasi experiment dengan menggunakan pendekatan pre-posttest with control group design (Nursalam, 2014). Populasi dalam penelitian ini adalah penderita hipertensi yang masuk dalam kriteria inklusi, yakni hipertensi yang tanpa komplikasi, mengalami tingkatan pre-hipertensi sampai pada hipertensi tingkat II sebanyak 40 sampel, yang terdiri dari 20 kelompok kontrol dan 20 kelompok intervensi. Teknik pengambilan sampel dalam penelitian ini adalah purposive sampling dengan kelompok eksperimen yang dilakukan intervensi pembekaman sedangkan pada kelompok control dilakukan pengukuran tekanan darah tanpa melakukan perlakuan. Analisis data yang digunakan dalam penelitian ini adalah dengan menggunakan uji friedman test.

\section{Prosedur Percobaan}

Kelompok eksperimen akan diberikan perlakuan dengan pembekaman pada titik hipertensi sebanyak satu kali dalam sebulan selama 3 bulan berturut-turut, sedangkan kelompok kontrol dilakukan observasi tekanan darah dengan tidak diberikan intervensi. Sebelum diberikan perlakuan, kelompok intervensi akan diukur tekanan darahnya 5 menit sebelum intervensi dilakukan (pre-test), lalu diberikan treatment (bekam), dan kemudian mengukur kembali tekanan darahnya (post-test) 5 menit setelah pembekaman. Pada setiap akhir bulan selama 3 bulan berturut-turut masa intervensi, evaluasi dilakukan dengan mengukur kembali tekanan darah responden.

\section{Prosedur Bekam Basah}

Prosedur bekam basah ini adalah 1) pada awalnya, kita menentukan titik bekam pada area kulit; 2) kemudian titik bekam tersebut didisinfeksi dengan menggunakan alkohol 70\%; 3) selanjutnya gelas bekam atau cupping ditempatkan pada titik-titik bekam yang telah ditentukan (sesuai keluhan); 4) diberikan tekanan negatif sehingga udara akan terkumpul dalam gelas; 5) biarkan selama 1-2 menit; 6) kemudian gelas akan dibuka dan membiarkan udara dalam gelas tadi keluar; 7) setelah itu, dilakukanlah penusukan atau penyayatan pada area epidermis kulit dengan menggunakan lanset sekali pakai atau bisturi; 8) kemudian, gelas akan ditempatkan kembali pada area titik bekam yang sama; 9) tekanan negatif diberikan lagi sehingga udara dan darah yang telah terkumpul 
pada area bekam tersedot keluar; 10) diamkan selama 3-5 menit; dan 11) setelah itu darah dikeluarkan dan dibersihkan area pembekamannya dengan tetap memperhatikan prinsip aseptik (Abdullah et al., 2016). Standardisasi praktik terapi bekam adalah langkah yang sangat penting untuk menghilangkan atau mengurangi efek samping terkait dengan bekam (Aboushanab \& AlSanad, 2018).

Beberapa efek samping ringan yang terjadi pada pasien bekam yakni rasa lemas, mengantuk, rasa haus, hematom atau kemerahan pada area titik pembekaman, dan rasa pegal setelah pembekaman. Namun, kondisi tersebut akan hilang dalam beberapa waktu ke depan, sedangkan efek samping yang berat biasanya terjadi lesi atau lepuhan pada area titik pembekaman yang diakibatkan karena lamanya pembukaan cup pada tindakan pembekaman sehingga sangat diperlukan tenaga ahli yang professional dalam melakukan tindakan pembekaman ini (Muflih \& Judha, 2019).

Instrumen dalam penelitian ini adalah dengan menggunakan alat bekam untuk melakukan intervensi kepada kelompok intervensi dan alat tensimeter serta stetoskop manual untuk mengukur tekanan darah kelompok intervensi dan kontrol (Aboushanab \& AlSanad, 2017). Analisis data dilakukan dengan uji friedman test dengan $\alpha \leq 0.05$ (Nursalam, 2014; Sartik et al., 2017). Uji normalitas diperoleh dari Shapiro-Wilk.

Penelitian ini telah mendapatkan izin etika dari Komisi etik penelitian Kesehatan Ikatan Ahli Kesehatan Masyarakat Indonesia (IAKMI) Provinsi Sulawesi Tenggara, Nomor 119a/KEPKIAKMI/IV/2020.

\section{HASIL DAN PEMBAHASAN}

\section{Karakteristik Responden}

Tabel 1 menunjukkan sebagian besar responden kelompok intervensi berumur antara 50-59 tahun (40\%), sedangkan umur responden kelompok kontrol terbesar ditemukan pada umur 60-69 tahun $(45 \%)$ dengan jenis kelamin terbanyak dari kedua kelompok yaitu perempuan: intervensi (75\%) dan kontrol (80\%).

Tabel 1. Karakteristik Responden

\begin{tabular}{llcccc}
\hline \multirow{2}{*}{ No. Karakteristik } & \multicolumn{2}{c}{ Kelompok Intervensi } & \multicolumn{2}{c}{ Kelompok Kontrol } \\
\cline { 2 - 5 } & Frekuensi & Persentase & Frekuensi & Persentase \\
\hline 1 & Usia (tahun) & 5 & & & 15 \\
& $40-49$ & 8 & 40 & 8 & 40 \\
& $50-59$ & 7 & 35 & 9 & 45 \\
& $60-69$ & & & & \\
2 & Jenis Kelamin & 5 & 25 & 4 & 20 \\
& Laki-laki & 15 & 75 & 16 & 80 \\
& Perempuan & &
\end{tabular}

Tabel ke-2, menunjukkan tekanan darah sistolik tertinggi sebelum terapi bekam sebesar $220 \mathrm{mmHg}$ (hipertensi tingkat II) dan terendah sebesar 130 $\mathrm{mmHg}$ (pre-hipertensi). Setelah dilakukan terapi bekam selama tiga bulan berturutturut didapatkan pada bulan ketiga tekanan darah sistolik tertinggi sebesar $180 \mathrm{mmHg}$ dan terendah sebesar 110 mmHg. Kemudian, tekanan darah diastolik ditemukan sebelum terapi bekam sebesar $110 \mathrm{mmHg}$ dan terendah sebesar $80 \mathrm{mmHg}$. Setelah terapi bekam, pada bulan ke-3 didapatkan tekanan darah diastolik yang tertinggi sebesar 100 $\mathrm{mmHg}$ dan terendah sebesar $70 \mathrm{mmHg}$, sedangkan pada kelompok kontrol, tekanan darah sistolik penderita hipertensi yang tidak menjalani terapi bekam pada bulan pertama sebesar 190 $\mathrm{mmHg}$ dan terendah sebesar $140 \mathrm{mmHg}$, kemudian pada bulan kedua sebesar 200 
Pengaruh Terapi Bekam terhadap Tekanan Darah...

mmHg dan terendah $140 \mathrm{mmHg}$, pada bulan ketiga tertinggi sebesar 190 dan terendah sebesar $100 \mathrm{mmHg}$. Pada tekanan diastolik di bulan pertama tertinggi sebesar $100 \mathrm{mmHg}$ dan terendah
$70 \mathrm{mmHg}$, bulan kedua tertinggi $110 \mathrm{mmHg}$ dan terendah $80 \mathrm{mmHg}$, serta di bulan ketiga tertinggi sebesar $120 \mathrm{mmHg}$ dan terendah sebesar $60 \mathrm{mmHg}$.

Tabel 2. Rerata Tekanan Darah Pasien Kelompok Intervensi dan Kontrol

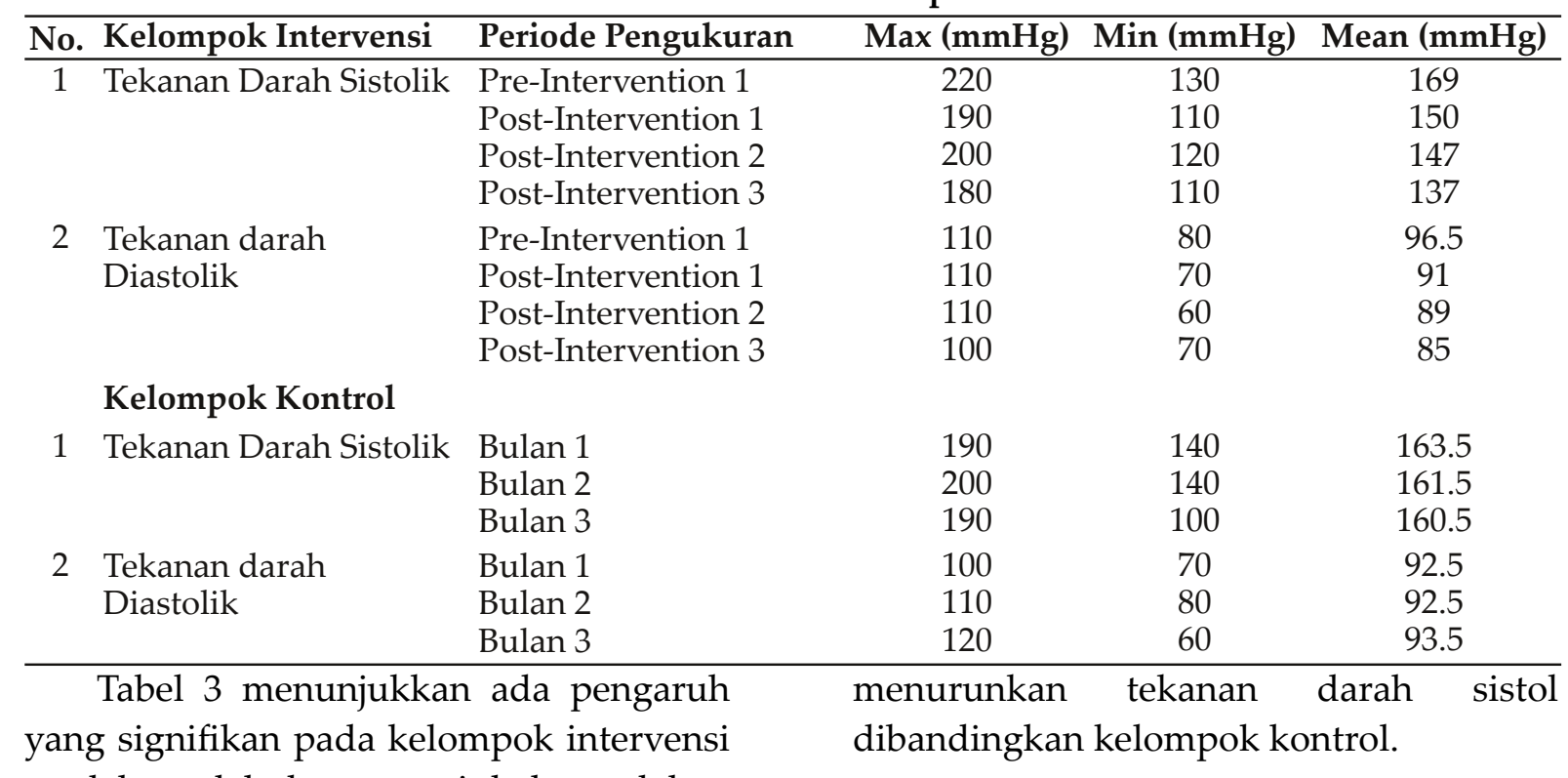
setelah melakukan terapi bekam dalam

Tabel 3. Analisis Tekanan Darah Pre and Post-Intervensi pada Kedua Kelompok

\begin{tabular}{ccccccc}
\hline No. & Tekanan darah & Kelompok & N & Chi-Square & df & Asymp.sig \\
\hline 1 & Tekanan Darah Sistolik & Intervensi & 20 & 23.479 & 3 & .000 \\
& & Kontrol & 20 & .000 & 2 & 1.000 \\
2 & Tekanan Darah & Intervensi & 20 & 20.033 & 3 & .000 \\
& Diastolik & Kontrol & 20 & .600 & 2 & .741 \\
\end{tabular}

\section{PEMBAHASAN}

Dari beberapa data demografi didapatkan bahwa penderita hipertensi terbanyak yakni pada rentang umur 50-59 tahun pada kelompok intervensi dan diikuti 60-69 tahun pada kelompok kontrol. Hal ini menunjukkan tingginya risiko penyakit hipertensi sejalan dengan semakin bertambahnya umur manusia, dengan umur yang merupakan faktor utama risiko terjadinya penyakit hipertensi. Penelitian terdahulu menemukan beberapa data demografi dalam hal ini usia sebagai faktor terbesar dari kejadian hipertensi, dengan umur di atas 40 tahun paling meningkat faktor risikonya ( $p=0.000)$ (Sartik et al., 2017). Faktor umur juga menjadi faktor risiko tertinggi kejadian hipertensi, dengan bukti bahwa umur 50 tahun ke atas memiliki frekuensi terbesar dari kejadian hipertensi (Hazwan \& Pinatih, 2017).

Penemuan ini menjelaskan bahwa, sejalan dengan umur yang semakin bertambah, struktur anatomi organ di dalam tubuh pun ikut mengalami beberapa perubahan, di ataranya struktur pembuluh darah arteri yang makin menipis dan tidak elastis yang mengakibatkan penampang pembuluh darah semakin menyempit sehingga hal ini membuat tekanan aliran darah semakin meningkat. Selain itu, beberapa penelitian menemukan jenis kelamin yang paling rentan dengan kejadian hipertensi adalah wanita, terutama pada wanita yang kurang patuh dalam mengonsumsi obat hipertensi (Pramana et al., 2019). Selain itu, wanita yang telah beranjak umur di atas 45 tahun merupakan awal persiapan terjadinya fase menopause karena kejadian tersebut mengakibatkan hormon 
estrogen yang memiliki manfaat besar dalam melindungi peredaran darah mengalami penurunan yang signifikan (Kusumawaty et al., 2016). Namun, beberapa penelitian yang lain melaporkan jenis kelamin laki-laki lebih berisiko dibanding dengan wanita dikarenakan faktor gaya hidup seperti merokok dan beban kerja yang dilakukan lebih banyak dialami oleh laki-laki (Tumanduk et al., 2019).

Hasil penelitian ini menunjukkan bahwa pemberian terapi bekam selama tiga bulan berturut-turut terbukti efektif menurunkan tekanan darah sistol maupun diastol pada penderita hipertensi dibandingkan dengan kelompok kontrol yang tidak diberikan kombinasi terapi bekam. Pada hasil analisis pre dan post pemberian terapi bekam pada tiap bulannya juga telah membuktikan bahwa terapi bekam efektif menurunkan tekanan darah pada penderita hipertensi. Hasil ini sejalan dengan penelitian yang sebelumnya, dimana dilaporkan bahwa terapi bekam memiliki pengaruh dalam menurunkan tekanan darah $(\mathrm{p}<0,05)$ (Astuti \& Syarifah, 2018). Hasil yang sama pula ditemukan dalam penelitian yang serupa, yaitu tekanan darah yang mengalami penurunan yang signifikan setelah dilakukan terapi bekam (Surahmat \& Damayanti, 2017).

Terapi bekam dari beberapa penelitian pada umumnya memberikan gambaran bahwa terapi bekam merupakan sebuah terapi komplementer yang aman dan nyaman digunakan (Lu et al., 2019). Hal tersebut dirasakan oleh beberapa pasien dalam penelitian ini saat beberapa jam setelah terapi bekam, dimana efek relaksasi yang dirasakan dan hilangnya nyeri kepala yang mereka rasakan membuat perasaan mereka terasa sangat nyaman setelah melakukan terapi bekam. Dapat dijelaskan secara fisiologis bahwa terapi bekam yang bekerja dalam menstimulasi penurunan tekanan darah melalui beberapa reaksi dari efek cupping yang dilakukan seperti menstimulasi aksi vasodilator seperti adenosin, noradrenalin, dan histamin yang diketahui dapat meningkatkan sirkulasi darah, dan merangsang sistem saraf otonom untuk menurunkan tekanan darah (Zarei et al., 2012). Mekanisme terapi bekam dalam menurunkan tekanan darah juga terjadi melalui pelepasan oksida nitrat yang menyebabkan pelebaran pembuluh darah, sehingga membuat pembuluh darah lebih kuat dan elastis, yang mengontrol hormon aldosteron sehingga volume darah yang mengalir di pembuluh darah menurun dan tekanan darah menurun secara stabil (Asmalinda \& Sapada, 2018).

Selain itu, tekanan negatif pada terapi bekam juga dapat mempengaruhi stimulus terjadinya penurunan tekanan darah, dengan hasil uji coba dalam sebuah penelitian yang menunjukkan bahwa 400-540 mbar dapat menurunkan tekanan sistol dan diastol darah sampai pada dua pekan kedepan (Zarei et al., 2012). Pada beberapa kondisi, pemberian tekanan negatif saat melakukan cupping lebih disarankan untuk dilakukan tidak terlalu kuat karena kondisi tersebut akan membuat rasa nyeri yang dapat mengakibatkan rasa trauma sehingga hal ini dapat menstimulasi hormon kortisol keluar. Oleh karena itu, beberapa keadaan tekanan darah justru akan lebih meningkat dari sebelumnya walaupun dengan melakukan cupping beberapa kali. Sebaiknya untuk mendapatkan hasil pembekaman dengan relaksasi yang maksimal, pemberian tekanan negatif dapat dilakukan dengan pemberian tekanan yang tidak terlalu kuat. Teknik ini dilakukan dalam penelitian ini sehingga efektifitas dapat ikut dianalisis secera verbal. Akhirnya, dalam penelitian studi fenomenologi dijelaskan bahwa beberapa pasien hipertensi memilih terapi bekam sebagai sebuah terapi alternatif dan komplementer yang aman, nyaman, dan ekonomis dalam mengendalikan tekanan 
darah mereka (Syahputra et al., 2019).

\section{KESIMPULAN}

Terapi bekam memiliki pengaruh yang signifikan dalam menurunkan tekanan darah sistolik dan diastolik pada penderita hipertensi hingga tiga bulan berturut-turut, sehingga dapat disimpulkan bahwa terapi bekam dapat digunakan sebagai terapi alternatif dan komplementer yang aman, nyaman, dan ekonomis baik dalam aspek preventif, kuratif, maupun rehabilitatif.

\section{UCAPAN TERIMA KASIH}

Peneliti mengucapkan terima kasih kepada Direktur Penelitian dan Pengabdian Masyarakat, Direktorat Jenderal Penelitian dan Pengembangan, Kementerian Riset dan Teknologi/Badan Riset dan Inovasi Nasional atas hibah melalui skim Penelitian Dosen Pemula dengan nomor kontrak 066/SP2H/LT/ DRPM/2020.

\section{DAFTAR PUSTAKA}

Abdullah, S. A., Mohd Najib, M. N., Dali, A. F., \& Sulaiman, S. (2016). Malay Cupping Therapy: A Haematological Analysis Pilot Study. In Regional Conference on Science, Technology and Social Sciences (RCSTSS 2014) (pp. 523529). Springer Singapore. https:// doi.org/10.1007/978-981-10-05343_52

Aboushanab, T., \& AlSanad, S. (2018). A brief illustration of the official national standards for the safe use of cupping therapy (Hijama) in Saudi Arabia. Journal of Integrative Medicine, 16(5), 297-298. https:// doi.org/10.1016/j.joim.2018.07.006

Aboushanab, T., \& AlSanad, S. M. (2017). Simulation in Cupping Training: An Innovation Method. Journal of Acupuncture and Meridian Studies, 10(6), 409-410. https:// doi.org/10.1016/j.jams.2017.10.003
Asmalinda, W., \& Sapada, E. (2018). The Effect of Wet Cupping (Hijama) Toward The Changing of Body Immune System in Venous Blood of Healthy Person. Jurnal Aisyah: Jurnal Ilmu Kesehatan, 3(2), 137-144. https://doi.org/10.30604/ jika.v3i2.121

Astuti, W., \& Syarifah, N. Y. (2018). Pengaruh Terapi Bekam Terhadap Tekanan Darah Pada Pasien Hipertensi Di Klinik Sehat Mugi Barokah Karakan Godean Sleman Yogyakarta. MIKKI (MIajalah Ilmu Keperawatan Dan Kesehatan Indonesia), 7(1). https://doi.org/ https://doi.org/10.47317/

mikki.v7i1.13

Hazwan, A., \& Pinatih, G. N. I. (2017). Gambaran karakteristik penderita hipertensi dan tingkat kepatuhan minum obat di wilayah kerja Puskesmas Kintamani I. Intisari Sains Medis, 8(2), 130-134. https:// doi.org/10.15562/ism.v8i2.127

Kemenkes RI. (2014). Info Datin Hipertensi. In Kementerian, Kesehatan. https:// www.kemkes.go.id/folder/view/01/ structure-publikasi-pusdatin-infodatin.html

Kementerian Kesehatan RI. (2018). Hasil Utama RISKESDAS 2018. https://kesmas.kemkes.go.id/assets/ upload/dir_519d41d8cd98f00/files/ Hasil-riskesdas-2018_1274.pdf

Kusumawaty, J., Hidayat, N., \& Ginanjar, E. (2016). Hubungan Jenis Kelamin dengan Intensitas Hipertensi pada Lansia di Wilayah Kerja Puskesmas Lakbok Kabupaten Ciamis. Mutiara Medika: Jurnal Kedokteran Dan Kesehatan, 16(2). https://doi.org/ https://doi.org/10.18196/ mmjkk.v16i2.4450

Lu, S., Du, S., Fish, A., Tang, C., Lou, Q., \& Zhang, X. (2019). Wet cupping for hypertension: a 
systematic review and metaanalysis. Clinical and Experimental Hypertension (New York, N.Y.: 1993), 41(5), 474-480. https:// doi.org/ 10.1080/10641963.2018.1510939

Muflih, M., \& Judha, M. (2019). Effectiveness of Blood Pressure Reduction Reviewed from Amount of Kop, Duration And Location of Point of Bekam Therapy. NurseLine Journal, 4(1), 46. https://doi.org/ 10.19184/nlj.v4i1.9042

Mukhlis, H., Hardono, Hermawan, N. S. A., Purwono, J., \& Wahyudi, D. A. (2020). Cupping Therapy For Hypertensive Patients: A QuasiExperimental Research With Time Series Design. Journal of Critical Reviews, 7(14), 1437-1443. https:// doi.org/10.31838/jcr.07.14.326

Nursalam. (2014). Metodologi Penelitian Ilmu Keperawatan. Salemba Medika.

Pramana, G. A., Dianingati, R. S., \& Saputri, N. E. (2019). Faktor-Faktor yang Mempengaruhi Kepatuhan Minum Obat Pasien Hipertensi Peserta Prolanis di Puskesmas Pringapus Kabupaten Semarang. IJPNP (Indonesian Journal of Pharmacy and Natural Product), 2(1). http://jurnal.unw.ac.id:1254/ index.php/ijpnp/article/view/196

Rahman, H. S., Ahmad, G. A., Mustapha, B., Al-Rawi, H. A., Hussein, R. H., Amin, K., Othman, H. H., \& Abdullah, R. (2020). Wet cupping therapy ameliorates pain in patients with hyperlipidemia, hypertension, and diabetes: A controlled clinical study. International Journal of Surgery Open, 26, 10-15. https://doi.org/ 10.1016/j.ijso.2020.07.003

Sartik, S., Tjekyan, R. S., \& Zulkarnain,
M. (2017). Risk Factors And The Incidence Of Hipertension In Palembang. Jurnal Ilmu Kesehatan Masyarakat, 8(3), 180-191. https:// doi.org/10.26553/jikm.2017.8.3.180191

Surahmat, R., \& Damayanti, N. R. (2017). Pengaruh Terapi Bekam Dalam Menurunkan Tekanan Darah Pada Pasien Hipertensi Di Rumah Bekam Palembang. Majalah Kedokteran Sriwijaya, 1, 43-49. https://core.ac.uk/download/pdf/ 267825455.pdf

Syahputra, A., Dewi, W. N., \& Novayelinda, R. (2019). Studi Fenomenologi: Kualitas Hidup Pasien Hipertensi Setelah Menjalani Terapi Bekam. Jurnal Ners Indonesia, 9(1), 19. https:// doi.org/10.31258/jni.9.1.19-32

Tumanduk, W. M., Nelwan, J. E., \& Asrifuddin, A. (2019). Faktorfaktor risiko hipertensi yang berperan di Rumah Sakit Robert Wolter Mongisidi. E-CliniC, 7(2). https://doi.org/10.35790/ecl. 7.2.2019.26569

Widada, W., Ontoseno, T., \& Purwanto, B. (2019). Pengaruh Terapi Bekam Basah Dalam Menurunkan Apoliprotein-B Pada Penderita Hiperkolesterolemia. Prosiding Seminar Nasional 2018 "Peran Dan Tanggung Jawab Tenaga Kesehatan Dalam Mendukung Program Kesehatan Nasional", 53-58. https://doi.org/10.32528/ psn.v0i0.1730

Zarei, M., Hejazi, S., Javadi, S. A., \& Farahani, H. (2012). The efficacy of wet cupping in the treatment of hypertension. ARYA Atherosclerosis Journal, 8, 1-4. http://arya.mui.ac.ir/ index.php/arya/article/view/316 